\title{
The effect of ash and compost on the content and bioaccumulation of selected heavy metals
}

\author{
Ewa Możdżer ${ }^{1}$, Krystyna Cybulska², Teresa Krzyśko-Lupickaª ${ }^{3}$ Edward Meller ${ }^{1}$ \\ ${ }^{1}$ West Pomeranian University of Technology, Szczecin, Department of Soil Science, Grassland Mangement and Environ- \\ mental Chemistry, Stowackiego17, 71-434 Szczecin, Poland \\ ${ }^{2}$ West Pomeranian University of Technology, Szczecin, Stowackiego17, 71-434 Szczecin, Department of Microbiology and \\ Biotechnology of Environment Stowackiego 17, 71-434 Szczecin, Poland \\ ${ }^{3}$ University of Opole, Department of Biotechnology and Molecular Biology, ul. Kardynała Kominka 4, 45-035 Opole, Poland \\ "Corresponding author: e-mail: ewa.mozdzer@zut.edu.pl
}

\begin{abstract}
Therefore the carried out study aimed at determination of the effect of high-calcium brown coal ash and compost being produced from municipal sewage sludge on the content and bioaccumulation of heavy metals in potato tubers, wheat grains and rapeseeds during a three-year period. Rapeseeds contained most $\mathrm{Cd}$ whereas wheat rains less. Potato tubers, wheat grains and rapeseeds contained more $\mathrm{Mn}, \mathrm{Ni}$ and $\mathrm{Zn}$ in the fertilization objects with municipal sewage sludge with or without coal ash and compared to those where calcium carbonate or coal ash had been introduced into the soil at a dose corresponding to $1.5 \mathrm{Mg} \mathrm{CaO} \cdot \mathrm{ha}^{-1}$ at the beginning of this study. Differences in the Mn, $\mathrm{Ni}$ and $\mathrm{Zn}$ contents in test plants between the fertilization objects with sewage sludge of with and without addition of ash were not significant.
\end{abstract}

Keywords: ash, compost, heavy metals, bioaccumulation, test plants.

\section{INTRODUCTION}

In recent years, Poland has seen an increase in prices of mineral fertilizers, while liming of arable land has been neglected. Changes have occurred in the crop structure which was beneficial for in favor of cereals and industrial crops. Ultimately, it leads to the imbalance in organic matter and nutrients in soils. Taking this situation into consideration, multidirectional research was conducted on the acquisition of environmentally friendly sources of organic matter and nutrients for plants.

During combustion of brown coal, process wastes are produced in the form of boiler slag, bottom ash and fly $\mathrm{ash}^{\mathbf{1}, 2}$. In Poland, the amount of high-calcium ash that was produced in the process of brown coal combustion is estimated to equal 4.5 million tons per year ${ }^{3}$.

High-calcium brown coal ash from the combustion process is characterized by different chemical composition. The alkaline reaction of brown coal fly ash and a considerable content of calcium and magnesium oxides in it has been shown in the studies ${ }^{4,5}$. Moreover, high-calcium brown coal ash contains in addition: As, $\mathrm{Ba}, \mathrm{Cd}, \mathrm{Cr}, \mathrm{Cu}, \mathrm{Mn}, \mathrm{Mo}, \mathrm{Pb}, \mathrm{Se}, \mathrm{Sr}, \mathrm{Zn}$ and other microelements. Municipal sewage sludge may be intended for fertilization purposes as it contains large amounts of organic matter. A factor limiting the direct use of municipal sewage sludge for fertilization purposes may be excessively caused by some heavy metals and polycyclic aromatic hydrocarbons (PAH), contamination with pathogenic microorganisms (Salmonella and others) and alimentary tractparasites ${ }^{6-9}$.

As a rule, combustion ash (waste) contains a smaller quantity of heavy metals than municipal sewage sludge ${ }^{10}$. In ash-sludge mixtures, the $\mathrm{pH}$ values increases together with the increase of ash percentage. The reaction corresponding to $\mathrm{pH} 10-11$ contributes to a decrease in solubility of heavy metals ${ }^{\mathbf{1 1}}$. Combustion ash is characterized by poor gravity drainage capacity and alkaline reaction and therefore may be used for the fixation of heavy metals being found in sewage sludge or compo- sts produced from them and the same mat limit their availability to plants ${ }^{12}$.

The study aimed at the determination of the effect of high-calcium brown coal ash and compost being produced from municipal sewage sludge by the GWDA method on the content and bioaccumulation of heavy metals in potato tubers, wheat grains, and rapeseeds during field experiment in a three-year period.

\section{MATERIAL AND METHODS}

In 2008-2010, a single-factor field experiment was carried out at the Cultivar Evaluation Stationin Szczecin-Dąbie. The soil on which this experiment was set up had been formed from light loamy sand (lls). With regard to its granulometric composition, it is classified into the category of light soils, of soil quality class IV b and good rye complex (5). The field experiment was composed of 6 fertilization objects. Examinations were carried out on $33 \mathrm{~m}^{2}$ plots, in four replications per each experimental object. In this field experiment, a crop rotation was applied according to the following pattern: potatoes of the cultivar Jasia in 2008, spring wheat of the cultivar Griva in 2009, and winter rapeseed of the cultivar Bazyl in 2010. The best fertilization effects were obtained in the system with municipal sewage sludge compost being applied at a dose corresponding to $250 \mathrm{~kg} \cdot \mathrm{ha}^{-1} \mathrm{~N}$ as well as with coal ash at a dose corresponding to $1.5 \mathrm{Mg}$ $\mathrm{CaO} \cdot \mathrm{ha}^{-1}$ being introduced into soil in the first year of study and at a dose corresponding to $0.75 \mathrm{Mg} \mathrm{CaO} \cdot \mathrm{ha}^{-1}$ in successive years. After introducing the compost with municipal sewage sludge, calcium carbonate and coal ash into the soil in spring 2008, the following mineral fertilization was applied:

- a multi-component fertilizer SuproFoska 20 was introduced into the soil at a dose of $400 \mathrm{~kg} \cdot \mathrm{ha}^{-1} 5.05 .2008$ (in the first year of experiment) prior to potatoes plantation. This dose corresponded to $28 \mathrm{~kg} \cdot \mathrm{ha}^{-1} \mathrm{P}$ and 66.4 $\mathrm{kg} \cdot \mathrm{ha}^{-1} \mathrm{~K}$. As far as nitrogen fertilizers are concerned, ammonium nitrate was introduced into the soil at a dose 
corresponding to $82 \mathrm{~kg} \mathrm{~N}$. Three days later potatoes were planted. During the second ridging, $34 \mathrm{~kg} \cdot \mathrm{ha}^{-1} \mathrm{~N}$ was introduced into the soil as top-dressing in the form of ammonium nitrate. The harvest of potato tubers was performed on 03.10.2008. In the fertilization objects with annual application of coal ash $\left(0.75 \mathrm{Mg} \mathrm{CaO} \cdot \mathrm{ha}^{-1}\right)$, it was introduced into the soil on 15.10. 2008 under spring wheat which was sowed in spring 2009;

- II year of the experiment, on 01.04.2009 a multi-component fertilizer Suprofos 25 was introduced into the soil at a dose of $400 \mathrm{~kg} \cdot \mathrm{ha}^{-1}$ prior to sowing spring wheat. On the same day, $150 \mathrm{~kg} \cdot \mathrm{ha}^{-1}$ of ammonium nitrate was introduced into the soil and on 03.04.2009 spring wheat was sowed. In the period of time between the shooting stage and the earring stage, a top dres sing fertilization was additionally applied in the form of ammonium nitrate at a dose corresponding to $34 \mathrm{~kg} \mathrm{~N}$. The harvest of spring wheat grains was performed on 14.08.2009. On 16-25.08.2009 cultivation measures were performed, coal ash was introduced into the soil in the fertilization objects $\left(0.75 \mathrm{Mg} \mathrm{CaO} \cdot \mathrm{ha}^{-1}\right)$ where it was applied each year, and $800 \mathrm{~kg} \cdot \mathrm{ha}^{-1}$ of multi-component fertilizer SuproFoska 20 was sowed and then the winter rapeseeds were sown; nitrogen fertilization was introduced into the soil as top-dressing in a dose $50 \mathrm{~kg} \cdot \mathrm{ha}^{-1} \mathrm{~N}$, 26.03and 16.04 in the third year of experiment (2010) in the form of ammonium nitrate. The harvest of winter rapeseeds was performed on 25.07.2010.

After reaching maturity, tested plants, were harvested every year and yield was expressed in $\mathrm{t} \cdot \mathrm{ha}^{-1}$. Average samples for each fertilization object were prepared from samples of tested plants. These average samples were used for determination of content of heavy metals. The heavy metal content of the test plants in the following years was determined in the medium samples for four replications of each fertilizers. The content of $\mathrm{Cd}, \mathrm{Cu}$, $\mathrm{Mn}, \mathrm{Ni}, \mathrm{Pb}$ and $\mathrm{Zn}$ was determined by atomic absorption spectrometry using a Perkin Elmer AAS 300 spectrometer. In compost, ash and the soil before the foundation experience, the contents of macroelement and heavy metals. N, Corg and S contents were determined on a Coestech CNS elemental analyzer, total $\mathrm{K}$ content by the method of flame photometry, and total $\mathrm{Mg}$ content by the method of atomic absorption spectrometry (AAS 300 ) and $\mathrm{P}$ content according to the Polish standard PN-98/C-04537-14. The stock solution was obtained after mineralization of compost, ash and soil according to standards PN-ISO 11466 and PN-ISO 11047, while soil $\mathrm{pH}$ value was determined by potentiometry in $1 \mathrm{~mol} \cdot \mathrm{dm}^{-3} \mathrm{KCl}(\mathrm{PN}-75 / \mathrm{C}-04540 / 05 / 01)$.

The study results were processed statistically by the analysis of variance in accordance with Statistica 8.0 PL computer software. In the case of significant differences, the Tukey's test was used at the significance level $p=0.05$.

Bioaccumulation factors in test plants for heavy metals were calculated as a ratio of the content of a given chemical element to the doses introduced into the soil with municipal sewage sludge compost and coal ash ${ }^{13}$. A four-point scale was adopted when evaluating the bioaccumulation factors of $\mathrm{Zn}, \mathrm{Pb}, \mathrm{Ni}, \mathrm{Mn}, \mathrm{Cd}$ and $\mathrm{Cu}$ in the test plant ${ }^{14}$. The degree of accumulation was determined as: intense, average, poor and none, whereas the corresponding values of bioaccumulation factors are 1.0 to $10.0 ; 0.1$ to $1.0 ; 0.1$ to 0.01 and 0.001 to 0.01 , respectively.

\section{RESULTS AND DISCUSSION}

The chemical characteristics of as well as that of municipal sewage sludge compost being produced by the GWDA method at the Municipal Sewage Treatment Plant in Stargard, coal ash coming from the Pątnów-Adamów-Konin Power Plant Complex and being used for soil fertilization, and soil before setting up this experiment, was published in the paper by Krzywy-Gawrońska ${ }^{15}$ (and now E. Możdżer), (Table 1, 2). Due to long descriptions of fertilization objects, acronyms were adopted for municipal Sewage Sludge Compost (SSC) and Brown Coal Ash (BCA) that were subsequently used in the discussion of research results. High content of calcium in the ash used in experiment allowed it to be classified into the group of high-calcium ashes. The total content of $\mathrm{Cd}, \mathrm{Mn}, \mathrm{Cr}$, $\mathrm{Zn}$, and $\mathrm{Ni}$ in the examined high-calcium ash used in experiment was higher than in municipal SSC. However, the total content of $\mathrm{Cu}$ and $\mathrm{Pb}$ was higher in compost with municipal sewage sludge when compared to high-calcium BCA. Taking into consideration the standards referring to the contents of heavy metals in fertilizers for soil de-acidification ${ }^{16}$, high-calcium BCA may be included among the factors affecting soil deacidification without negative environmental impact. Heavy metals are absorbed by plants passively, actively or by using both these methods. Their presence in plants depends mainly

Table 1. The $\mathrm{pH}$ value and the content of dry matter, organic carbon, macroelements and heavy metals in municipal sewage sludge compost and brown coal ash

\begin{tabular}{|c|c|c|c|c|c|c|c|c|c|c|c|c|c|c|}
\hline \multirow[b]{2}{*}{$\mathrm{pH}$} & \multicolumn{7}{|c|}{ Total content in $\mathrm{g} \cdot \mathrm{kg}^{-1} \mathrm{~d} . \mathrm{m}$. } & \multicolumn{7}{|c|}{ Total content in $\mathrm{mg} \cdot \mathrm{kg}^{-1} \mathrm{~d} . \mathrm{m}$. } \\
\hline & $\begin{array}{c}\text { dry } \\
\text { matter }\end{array}$ & $\mathrm{N}$ & $\mathrm{P}$ & $\mathrm{K}$ & $\mathrm{Ca}$ & $\mathrm{Mg}$ & Corg. & $\mathrm{Cd}$ & $\mathrm{Cu}$ & $\mathrm{Mn}$ & $\mathrm{Ni}$ & $\mathrm{Pb}$ & $\mathrm{Zn}$ & $\mathrm{Cr}$ \\
\hline \multicolumn{15}{|c|}{ Compost with municipal sewage sludge (SSC) } \\
\hline $\begin{array}{c}\mathrm{pH} \mathrm{H} 2 \mathrm{O} \\
8.50\end{array}$ & 340 & 18.0 & 10.2 & 3.58 & 7.0 & 1.0 & 286 & 1.05 & 47.0 & 259 & 8.61 & 54 & 140 & 15.5 \\
\hline \multicolumn{15}{|c|}{ High-calcium brown coal ash (BCA) } \\
\hline $\begin{array}{c}\mathrm{pHKCl} \\
11.0\end{array}$ & 986 & lack & 2.52 & 5.50 & 145 & 12.5 & lack & 2.77 & 27.6 & 265 & 12.6 & 16.2 & 231 & 20.6 \\
\hline
\end{tabular}

Table 2. Total content of the total macroelements and heavy metals in the soil before the foundation experience

\begin{tabular}{|c|c|c|c|c|c|c|c|c|c|c|c|c|c|}
\hline \multirow{2}{*}{$\mathrm{pH}_{\mathrm{KCl}}$} & \multirow{2}{*}{ Corg. } & \multicolumn{6}{|c|}{ Total content $\mathrm{g} \cdot \mathrm{kg}^{-1} \mathrm{~d} . \mathrm{m}$. } & \multicolumn{6}{|c|}{ Total content $\mathrm{mg} \cdot \mathrm{kg}^{-1} \mathrm{~d} . \mathrm{m}$. } \\
\hline & & $\mathrm{N}$ & $\mathrm{P}$ & $\mathrm{K}$ & $\mathrm{Ca}$ & $\mathrm{Mg}$ & $\mathrm{S}$ & $\mathrm{Cd}$ & $\mathrm{Cu}$ & $\mathrm{Mn}$ & $\mathrm{Ni}$ & $\mathrm{Pb}$ & $\mathrm{Zn}$ \\
\hline 5.3 & 8.50 & 0.72 & 0.45 & 0.62 & 0.78 & 0.62 & 0.08 & 0.22 & 9.50 & 205 & 9.50 & 19.2 & 24.0 \\
\hline
\end{tabular}


on their soil concentration, plant species, developmental stage and plant part ${ }^{17-18}$. The natural content of heavy metals did not induce any negative impact on the yield quality. Potato absorbs, among other, $60-70 \mathrm{mg} \mathrm{Cu}$, $450-500 \mathrm{mg} \mathrm{Zn}$ and $700-750 \mathrm{mg} \mathrm{Mn}$ when producing 40 $\mathrm{Mg} \cdot \mathrm{ha}^{-1}$ of tubers ${ }^{19}$. In the first year of experiment, the content of heavy metals in potato tubers, wheat grains, and rapeseeds differed and depended on the fertilization being applied.

Winter rapeseeds contained most $\mathrm{Cd}$, from 0.06 to $0.08 \mathrm{mg} \cdot \mathrm{kg}^{-1} \mathrm{~d}$.m. Less $\mathrm{Cd}$ was found in spring wheat grains, from 0.04 to $0.06 \mathrm{mg} \cdot \mathrm{kg}^{-1} \mathrm{~d} . \mathrm{m}$. and in potato tubers, from 0.03 to $0.05 \mathrm{mg} \cdot \mathrm{kg}^{-1} \mathrm{~d} . \mathrm{m}$. Differences in the $\mathrm{Cd}$ content in potato tubers, spring wheat grains, and winter rapeseeds between respective experimental objects were not significant (Table 3). The content of $\mathrm{Cu}$ in potato tubers ranged from 5.65 to $6.05 \mathrm{mg} \cdot \mathrm{kg}^{-1} \mathrm{~d} . \mathrm{m}$. Differences in its content in potato tubers between respective experimental objects were not significant. The highest $\mathrm{Cu}$ content was characteristic of spring wheat grains from the fertilization objects with municipal SSC, being introduced into the soil at a dose corresponding to $250 \mathrm{~kg} \mathrm{~N} \cdot \mathrm{ha}^{-1}$ without and with addition of highcalcium BCA applied at the beginning of the experiment and each year, i.e. from 5.09 to $5.11 \mathrm{mg} \mathrm{Cu} \cdot \mathrm{kg}^{-1}$ d.m. (objects $\mathrm{C}, \mathrm{D}$ and F). Differences in the $\mathrm{Cu}$ content in test plant grains between the objects mentioned above (objects C, D and F) were not significant. Spring wheat grains in the fertilization objects $\mathrm{C}, \mathrm{D}$ and $\mathrm{F}$ contained significantly more $\mathrm{Cu}$ when compared to that with calcium carbonate and high-calcium BCA being applied at a dose corresponding to $1.5 \mathrm{Mg} \mathrm{CaO} \cdot \mathrm{ha}^{-1}$ (objects
A, B). Differences in the $\mathrm{Cu}$ content in spring wheat grains from fertilization objects $\mathrm{A}, \mathrm{B}$ and $\mathrm{E}$ were not significant. The highest $\mathrm{Cu}$ content was characteristic of rapeseeds from the fertilization objects with municipal SSC and with annual application of high-calcium BCA, at a level of $3.36 \mathrm{mg} \cdot \mathrm{kg}^{-1}$ d.m. Least $\mathrm{Cu}$ contained by rapeseeds $2.75 \mathrm{mg} \cdot \mathrm{kg}^{-1} \mathrm{~d}$.m. from the fertilization object with calcium carbonate being introduced into the soil at a dose corresponding to $1.5 \mathrm{Mg} \mathrm{CaO} \cdot \mathrm{ha}^{-1}$ (object $\mathrm{A}$ ). No significant differences in the $\mathrm{Cu}$ content in rapeseeds were found. More Mn contained potato tubers, wheat grains and rapeseeds from the fertilization objects with municipal SSC with and without the addition of high-calcium BCA when compared to those where calcium carbonate or high-calcium BCA had been introduced into the soil at the beginning of this study at a dose corresponding to $1.5 \mathrm{Mg} \mathrm{CaO} \cdot \mathrm{ha}^{-1}$.

Content in these fertilization objects fluctuated from 22.5 to $22.8 \mathrm{mg} \cdot \mathrm{kg}^{-1} \mathrm{~d}$.m. Difference in the Mn content in potato tubers, wheat grains, and rapeseeds between the fertilization objects with municipal SSC with and without the addition of high-calcium BCA were not significant. Nevertheless, an average increase in the Mn content was observed in potato tubers (by $9.40 \%$ ), wheat grains (by 22.4\%) and rapeseeds (by 18.2\%) between fertilization objects $\mathrm{C}, \mathrm{D}, \mathrm{E}$ and object $\mathrm{A}$. High-calcium BCA that was introduced into the soil at the beginning of this study and each year (objects A, E) induced a significant increase in the Mn content only in rapeseeds when compared to the object with calcium carbonate (object A). Differences in the Mn content in potato tubers and wheat grains between these fertiliza-

Table 3. $\mathrm{Cd}, \mathrm{Cu}, \mathrm{Mn}, \mathrm{Ni}, \mathrm{Pb}$ and $\mathrm{Zn}$ contents in the test plants cultivated under crop rotation

\begin{tabular}{|c|c|c|c|c|c|c|c|c|}
\hline \multirow{3}{*}{$\begin{array}{l}\text { Chemical } \\
\text { element }\end{array}$} & \multirow{3}{*}{ Plant } & \multicolumn{6}{|c|}{ Fertilisationobjetcs } & \multirow{3}{*}{$\operatorname{LSD}_{0.05}$} \\
\hline & & $A^{*}$ & $\mathrm{~B}$ & $\mathrm{C}$ & $\mathrm{D}$ & $E$ & $\mathrm{~F}$ & \\
\hline & & \multicolumn{6}{|c|}{ Total content $\left(\mathrm{mg} \cdot \mathrm{kg}^{-1}\right)$} & \\
\hline \multirow{3}{*}{$\mathrm{Cd}$} & \multirow{3}{*}{$\begin{array}{c}\text { Potato } \\
\text { Wheat Rape }\end{array}$} & 0.03 & 0.04 & 0.05 & 0.05 & 0.04 & 0.05 & $\mathrm{~ns}$ \\
\hline & & 0.04 & 0.04 & 0.06 & 0.06 & 0.04 & 0.06 & ns \\
\hline & & 0.06 & 0.06 & 0.08 & 0.08 & 0.06 & 0.08 & ns \\
\hline \multicolumn{2}{|l|}{ mean } & 0.04 & 0.05 & 0.06 & 0.06 & 0.05 & 0.06 & ns \\
\hline \multirow{3}{*}{$\mathrm{Cu}$} & \multirow{4}{*}{$\begin{array}{c}\text { Potato } \\
\text { Wheat Rape }\end{array}$} & 5.65 & 5.75 & 5.98 & 6.05 & 5.80 & 6.02 & ns \\
\hline & & 4.55 & 4.58 & 5.08 & 5.06 & 4.65 & 5.11 & 0.46 \\
\hline & & 2.75 & 3.02 & 3.26 & 3.28 & 3.15 & 3.36 & 0.06 \\
\hline mean & & 4.32 & 4.45 & 4.77 & 4.79 & 4.53 & 4.83 & 0.05 \\
\hline \multirow{3}{*}{$\mathrm{Mn}$} & \multirow{4}{*}{$\begin{array}{c}\text { Potato } \\
\text { Wheat Rape }\end{array}$} & 20.6 & 20.8 & 22.5 & 22.3 & 20.5 & 22.8 & 1.77 \\
\hline & & 20.1 & 20.5 & 24.8 & 24.4 & 20.6 & 24.6 & 3.78 \\
\hline & & 22.0 & 23.6 & 25.7 & 25.8 & 24.0 & 26.5 & 0.87 \\
\hline mean & & 20.9 & 21.6 & 24.3 & 24.2 & 21.7 & 24.6 & 0.14 \\
\hline \multirow{3}{*}{$\mathrm{Ni}$} & \multirow{4}{*}{$\begin{array}{c}\text { Potato } \\
\text { Wheat Rape }\end{array}$} & 1.15 & 1.20 & 1.30 & 1.32 & 1.17 & 1.32 & $\mathrm{~ns}$ \\
\hline & & 0.23 & 0.23 & 0.29 & 0.31 & 0.23 & 0.30 & 0.10 \\
\hline & & 2.00 & 2.01 & 2.99 & 3.01 & 2.06 & 3.10 & 0.20 \\
\hline mean & & 1.12 & 1.14 & 1.53 & 1.55 & 1.15 & 1.58 & 0.02 \\
\hline \multirow{3}{*}{$\mathrm{Pb}$} & & 2.02 & 2.15 & 2.65 & 2.55 & 2.13 & 2.52 & 0.32 \\
\hline & Potato & 0.48 & 0.49 & 0.58 & 0.59 & 0.45 & 0.57 & 0.12 \\
\hline & & 1.15 & 1.20 & 1.65 & 1.62 & 1.25 & 1.62 & 0.13 \\
\hline \multicolumn{2}{|l|}{ mean } & 1.27 & 1.28 & 1.63 & 1.59 & 1.28 & 1.57 & 0.01 \\
\hline \multirow{3}{*}{$\mathrm{Zn}$} & Potato & 17.4 & 17.5 & 19.8 & 19.9 & 17.4 & 19.8 & 2.75 \\
\hline & Potato & 26.3 & 26.0 & 30.5 & 30.1 & 27.4 & 30.8 & ns \\
\hline & & 28.4 & 29.5 & 32.1 & 32.8 & 30.0 & 33.5 & 1.06 \\
\hline \multicolumn{2}{|l|}{ mean } & 24.0 & 24.3 & 27.4 & 27.6 & 24.9 & 28.0 & 0.12 \\
\hline
\end{tabular}

*Description of fertilization objects: A - Carbonate lime $\left(\mathrm{CaCO}_{3}\right)$ at a dose corresponding to $1.5 \mathrm{Mg} \mathrm{CaO} \cdot \mathrm{ha}{ }^{-1}, \mathrm{~B}-\mathrm{High}-\mathrm{calcium}$ brown coal ash at a dose corresponding to $1.5 \mathrm{Mg} \mathrm{CaO} \cdot \mathrm{ha}^{-1}, \mathrm{C}$ - Municipal sewage sludge compost at a dose corresponding to

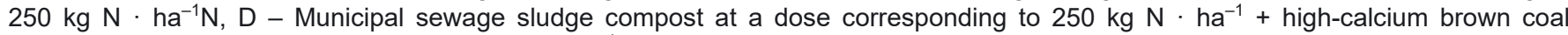
ash at a dose corresponding to $1.5 \mathrm{Mg} \mathrm{CaO} \cdot \mathrm{ha}^{-1}$ in the first year of experiment, $\mathrm{E}$ - High-calcium brown coal ash at a dose corresponding to $1.5 \mathrm{Mg} \mathrm{CaO} \cdot \mathrm{ha}^{-1}$ in the first year of experiment, with $0.75 \mathrm{Mg} \mathrm{CaO} \cdot \mathrm{ha}^{-1}$ in next years each, $\mathrm{F}-\mathrm{Municipal}$ sewage sludge compost at a dose corresponding to $250 \mathrm{~kg} \mathrm{~N} \cdot \mathrm{ha}^{-1}+$ high- calcium brown coal ash at a dose corresponding to $1.5 \mathrm{Mg}$ $\mathrm{CaO} \cdot \mathrm{ha}^{-1}$ in the first year of experiment, with $0.75 \mathrm{Mg} \mathrm{CaO} \cdot \mathrm{ha}^{-1}$ in next years each 
tion objects were not significant. More Ni was contained in potato tubers, wheat grains, and rapeseeds from the fertilization objects with municipal SSC with and without the addition of high-calcium BCA when compared to those in which calcium carbonate or high-calcium BCA had been applied at a dose corresponding to $1.5 \mathrm{Mg}$ $\mathrm{CaO} \cdot \mathrm{ha}^{-1}$. No significant differences in the Ni content were found in potato tubers between respective fertilization objects (Table 4). Despite the lack of significant differences in the $\mathrm{Ni}$ content, its average increase was found in potato tubers (by $11.5 \%$ ). Significantly more $\mathrm{Ni}$ contained wheat grains and rapeseeds from the fertilization objects with municipal SSC with and without the addition of high-calcium BCA when compared to those in which calcium carbonate or high-calcium BCA had been applied (Table 3 ). More $\mathrm{Pb}$ was contained in potato tubers, wheat grains, and rapeseeds from the objects with municipal SSC without and with addition of high-calcium BCA (objects C, D, F) when compared to those in which calcium carbonate or high-calcium BCA had been introduced into the soil. One hand, differences in the $\mathrm{Pb}$ content in test plants between these groups of fertilization objects were significant. On the other hand, no significant differences in the $\mathrm{Pb}$ content were found in test plants between municipal SSC with and without the addition of high-calcium BCA. An average increase in the $\mathrm{Pb}$ content in test plants in the fertilization object with high-calcium BCA amounted to $0.78 \%$ when compared to that with exclusive calcium carbonate fertilization. The $\mathrm{Zn}$ content in potato tubers, wheat grains, and rapeseeds in the objects with municipal SSC with and without the addition of high-calcium BCA (objects C, D, E) was higher in the content of objects in which calcium carbonate or high-calcium BCA had been introduced into the soil (objects A, B). The one hand, differences in the $\mathrm{Zn}$ content in potato tubers and rapeseeds between the fertilization objects mentioned above were significant. On the other hand, differences in the $\mathrm{Zn}$ content in spring wheat grains between respective fertilization objects of this experiment were not significant. Nevertheless, an average increase of the zinc content was found in wheat grains, of by $16.6 \%$, between fertilization objects C, D, F and objects $\mathrm{A}$ and $\mathrm{B}$. No significant difference in the $\mathrm{Zn}$ content was found in potato tubers between fertilization objects A, B and E. To sum up, it is possible to state that most heavy metals in potato tubers, wheat grains, and rapeseeds were found after the application of municipal SSC with or without the addition of high-calcium BCA (objects C, D, F). A difference between the maximum and the minimum contents of heavy metals in potato

Table 4. Bioaccumulation index of heavy metals in potato tubers, wheat grains, and rapeseeds as affected by municipal sewage sludge compost and high-calcium brown coal ash

\begin{tabular}{|c|c|c|c|c|c|c|}
\hline \multirow{2}{*}{$\begin{array}{c}\text { Fertilization } \\
\text { objects }\end{array}$} & \multicolumn{6}{|c|}{ Chemical element } \\
\hline & $\mathrm{Cd}$ & $\mathrm{Cu}$ & $\mathrm{Mn}$ & $\mathrm{Ni}$ & $\mathrm{Pb}$ & $\mathrm{Zn}$ \\
\hline \multicolumn{7}{|c|}{ potato tubers } \\
\hline B & $\begin{array}{l}0.009 \\
\text { none }\end{array}$ & $\begin{array}{c}0.138 \\
\text { average }\end{array}$ & $\begin{array}{l}0.052 \\
\text { poor }\end{array}$ & $\begin{array}{l}0.063 \\
\text { poor }\end{array}$ & $\begin{array}{l}0.089 \\
\text { poor }\end{array}$ & $\begin{array}{l}0.050 \\
\text { poor }\end{array}$ \\
\hline C & $\begin{array}{c}0.190 \\
\text { average }\end{array}$ & $\begin{array}{c}0.508 \\
\text { average }\end{array}$ & $\begin{array}{c}0.347 \\
\text { average }\end{array}$ & $\begin{array}{c}0.604 \\
\text { average }\end{array}$ & $\begin{array}{c}0.196 \\
\text { average }\end{array}$ & $\begin{array}{c}0.565 \\
\text { average }\end{array}$ \\
\hline D & $\begin{array}{l}0.011 \\
\text { poor }\end{array}$ & $\begin{array}{c}0.113 \\
\text { average }\end{array}$ & $\begin{array}{l}0.048 \\
\text { poor }\end{array}$ & $\begin{array}{c}0.062 \\
\text { poor }\end{array}$ & $\begin{array}{c}0.067 \\
\text { poor }\end{array}$ & $\begin{array}{l}0.052 \\
\text { poor }\end{array}$ \\
\hline$E$ & $\begin{array}{l}0.006 \\
\text { none }\end{array}$ & $\begin{array}{c}0.102 \\
\text { average }\end{array}$ & $\begin{array}{l}0.034 \\
\text { poor }\end{array}$ & $\begin{array}{l}0.041 \\
\text { poor }\end{array}$ & $\begin{array}{l}0.058 \\
\text { poor }\end{array}$ & $\begin{array}{l}0.033 \\
\text { poor }\end{array}$ \\
\hline $\mathrm{F}$ & $\begin{array}{l}0.007 \\
\text { none }\end{array}$ & $\begin{array}{c}0.081 \\
\text { poor }\end{array}$ & $\begin{array}{l}0.035 \\
\text { poor }\end{array}$ & $\begin{array}{l}0.044 \\
\text { poor }\end{array}$ & $\begin{array}{l}0.050 \\
\text { poor }\end{array}$ & $\begin{array}{c}0.035 \\
\text { poor }\end{array}$ \\
\hline Mean value & $\begin{array}{l}0.044 \\
\text { poor }\end{array}$ & $\begin{array}{c}0.186 \\
\text { average }\end{array}$ & $\begin{array}{c}0.103 \\
\text { average }\end{array}$ & $\begin{array}{c}0.162 \\
\text { average }\end{array}$ & $\begin{array}{l}0.092 \\
\text { poor }\end{array}$ & $\begin{array}{c}0.147 \\
\text { average }\end{array}$ \\
\hline \multicolumn{7}{|c|}{ Wheat grains } \\
\hline B & $\begin{array}{l}0.010 \\
\text { none }\end{array}$ & $\begin{array}{c}0.110 \\
\text { average }\end{array}$ & $\begin{array}{l}0.050 \\
\text { poor }\end{array}$ & $\begin{array}{c}0.012 \\
\text { poor }\end{array}$ & $\begin{array}{l}0.020 \\
\text { poor }\end{array}$ & $\begin{array}{l}0.070 \\
\text { poor }\end{array}$ \\
\hline C & $\begin{array}{c}0.229 \\
\text { average }\end{array}$ & $\begin{array}{c}0.432 \\
\text { average }\end{array}$ & $\begin{array}{c}0.383 \\
\text { average }\end{array}$ & $\begin{array}{c}0.134 \\
\text { average }\end{array}$ & $\begin{array}{c}0.042 \\
\text { poor }\end{array}$ & $\begin{array}{c}0.871 \\
\text { average }\end{array}$ \\
\hline D & $\begin{array}{c}0.013 \\
\text { poor }\end{array}$ & $\begin{array}{c}0.095 \\
\text { poor }\end{array}$ & $\begin{array}{c}0.052 \\
\text { poor }\end{array}$ & $\begin{array}{c}0.014 \\
\text { poor }\end{array}$ & $\begin{array}{l}0.015 \\
\text { poor }\end{array}$ & $\begin{array}{c}0.078 \\
\text { poor }\end{array}$ \\
\hline$E$ & $\begin{array}{l}0.006 \\
\text { none }\end{array}$ & $\begin{array}{c}0.074 \\
\text { poor }\end{array}$ & $\begin{array}{l}0.037 \\
\text { poor }\end{array}$ & $\begin{array}{l}0.008 \\
\text { none }\end{array}$ & $\begin{array}{c}0.012 \\
\text { poor }\end{array}$ & $\begin{array}{c}0.052 \\
\text { poor }\end{array}$ \\
\hline $\mathrm{F}$ & $\begin{array}{l}0.009 \\
\text { none }\end{array}$ & $\begin{array}{c}0.069 \\
\text { poor }\end{array}$ & $\begin{array}{c}0.032 \\
\text { poor }\end{array}$ & $\begin{array}{l}0.010 \\
\text { poor }\end{array}$ & $\begin{array}{l}0.011 \\
\text { poor }\end{array}$ & $\begin{array}{c}0.055 \\
\text { poor }\end{array}$ \\
\hline Mean value & $\begin{array}{l}0.053 \\
\text { poor }\end{array}$ & $\begin{array}{c}0.156 \\
\text { average }\end{array}$ & $\begin{array}{c}0.111 \\
\text { average }\end{array}$ & $\begin{array}{l}0.035 \\
\text { poor }\end{array}$ & $\begin{array}{l}0.020 \\
\text { poor }\end{array}$ & $\begin{array}{c}0.226 \\
\text { average }\end{array}$ \\
\hline \multicolumn{7}{|c|}{ Rape seeds } \\
\hline B & $\begin{array}{l}0.014 \\
\text { poor }\end{array}$ & $\begin{array}{l}0.073 \\
\text { poor }\end{array}$ & $\begin{array}{c}0.059 \\
\text { poor }\end{array}$ & $\begin{array}{c}0.106 \\
\text { average }\end{array}$ & $\begin{array}{c}0.049 \\
\text { poor }\end{array}$ & $\begin{array}{l}0.085 \\
\text { poor }\end{array}$ \\
\hline C & $\begin{array}{c}0.305 \\
\text { average }\end{array}$ & $\begin{array}{c}0.277 \\
\text { average }\end{array}$ & $\begin{array}{c}0.387 \\
\text { average }\end{array}$ & $\begin{array}{c}1.390 \\
\text { intense }\end{array}$ & $\begin{array}{c}0.042 \\
\text { average }\end{array}$ & $\begin{array}{c}0.871 \\
\text { average }\end{array}$ \\
\hline D & $\begin{array}{c}0.018 \\
\text { poor }\end{array}$ & $\begin{array}{c}0.061 \\
\text { poor }\end{array}$ & $\begin{array}{c}0.056 \\
\text { poor }\end{array}$ & $\begin{array}{c}0.143 \\
\text { average }\end{array}$ & $\begin{array}{c}0.043 \\
\text { poor }\end{array}$ & $\begin{array}{c}0.086 \\
\text { poor }\end{array}$ \\
\hline $\mathrm{F}$ & $\begin{array}{l}0.012 \\
\text { none }\end{array}$ & $\begin{array}{c}0.046 \\
\text { poor }\end{array}$ & $\begin{array}{l}0.041 \\
\text { poor }\end{array}$ & $\begin{array}{c}0.102 \\
\text { average }\end{array}$ & $\begin{array}{c}0.032 \\
\text { poor }\end{array}$ & $\begin{array}{l}0.060 \\
\text { poor }\end{array}$ \\
\hline Mean value & $\begin{array}{l}0.072 \\
\text { poor }\end{array}$ & $\begin{array}{c}0.102 \\
\text { average }\end{array}$ & $\begin{array}{c}0.119 \\
\text { average }\end{array}$ & $\begin{array}{c}0.363 \\
\text { average }\end{array}$ & $\begin{array}{l}0.060 \\
\text { poor }\end{array}$ & $\begin{array}{c}0.241 \\
\text { average }\end{array}$ \\
\hline
\end{tabular}

* Description of fertilization objects is given in Table 3 
tubers in this experiment amounted to $66.7 \%$ for $\mathrm{Cd}, 7.1 \%$ for $\mathrm{Cu}, 10.7 \%$ for $\mathrm{Mn}, 14.8 \%$ for $\mathrm{Ni}, 31.2 \%$ for $\mathrm{Pb}$ and $14.4 \%$ for $\mathrm{Zn}$, while that in wheat grains amounted to $50 \% ; 12.3 \% ; 22.4 \% ; 30.4 \% ; 31.1 \%$ and $18.5 \%$ and in rapeseeds to $33.3 \% ; 22.2 \%, 20.4 \% ; 55.0 \% ; 28.3 \%$ and $16.7 \%$, respectively.

The test plants fertilized with municipal SSC and high-calcium BCA which was applied each year, followed by municipal SSC with and without the addition of high-calcium BCA, contained more heavy metals than those from the fertilization objects with calcium carbonate and high-calcium BCA. The content of heavy metals in test plants did not exceed the acceptable standards that do not induce their contamination. An increase in the content of heavy metals in plants after the application of municipal SSC was also observed ${ }^{\mathbf{2 0 - 2 2}}$. The composts in which sewage sludge is the main component, may induce an increased accumulation of heavy metals in plants. According to the data published the composts in which sewage sludge is the main component, may induce an increased accumulation of heavy metals in plants ${ }^{23}$. High-calcium ash from the Pątnów-Adamów-Konin Power Plant Complex being applied to light soil of good rye complex do not induce changes in the chemical composition and the sowing value of wheat grains $^{24}$. However, in the opinion of Gibczyńska et al. ${ }^{\mathbf{2 5}}$ the application of high-calcium ash induces an increase in the amount of $\mathrm{Mn}$ (about $25 \%$ in relation to the control object A) in spring triticale grains. In these studies, no significant differences were found in the effects of traditional calcium fertilizers and high-calcium ash on the yield quality of triticale and wheat. The application of mineral and organic fertilizers is meant to increase the yield of crop plants. Mineral fertilizers usually have an effect in the period of one year, whereas organic fertilizers need much longer time, lasting even few years.

Potato tubers, wheat grains, and rapeseeds did not contain excessive amounts of $\mathrm{Cd}, \mathrm{Cu}, \mathrm{Mn}, \mathrm{Ni}, \mathrm{Pb}$ and $\mathrm{Zn}$ because they had not been introduced into the soil in considerable quantities with municipal SSC and high-calcium BCA, while the soil itself did not contain their excess amounts. When evaluating the use fulness of potato tubers, wheat grains, and rapeseeds for utilization of heavy metals from the compost produced from municipal sewage sludge and high-calcium BCA, bioaccumulation indices for $\mathrm{Cd}, \mathrm{Cu}, \mathrm{Mn}, \mathrm{Ni}, \mathrm{Pb}$ and $\mathrm{Zn}$ were calculated.

The degree of bioaccumulation of the chemical elements under analysis in potato tubers, wheat grains, and rapeseeds differed, depending on the fertilization applied. When calculating the bioaccumulation index, fertilization object A was ignored, where no municipal SSC or high-calcium BCA had been applied (Table 4). The degree of $\mathrm{Cd}, \mathrm{Cu}, \mathrm{Mn}, \mathrm{Ni}, \mathrm{Pb}$ and $\mathrm{Zn}$ accumulation in potato tubers in the first years of this study was average in the fertilization object with municipal SSC being applied at a dose corresponding to $250 \mathrm{~kg} \cdot \mathrm{ha}^{-1} \mathrm{~N}$ (Table 4). The objects with high-calcium BCA which were introduced into the soil (objects B, E), were characterized by poor accumulation degree in case of $\mathrm{Mn}, \mathrm{Ni}, \mathrm{Pb}$ average one for $\mathrm{Cu}$ and the lack of bioaccumulation for $\mathrm{Cd}$.

The average degree of accumulation in potato tubers characterized copper (0.103) in the object of municipal SSC introduced into the soil with high-calcium BCA (object D),whereas other heavy metals reached a poor degree. In the object of municipal SSC introduced into the soil at a dose corresponding to $250 \mathrm{~kg} \mathrm{~N} \cdot \mathrm{ha}^{-1}$ and high-calcium BCA at a dose corresponding to $1.5 \mathrm{Mg}$ $\mathrm{CaO} \cdot \mathrm{ha}^{-1}$ (object $\mathrm{F}$ ), the degree of accumulation in potato tubers for all examined chemical elements was poor, while there was a lack of $\mathrm{Cd}$ accumulation.

$\mathrm{Zn}, \mathrm{Pb}, \mathrm{Mn}$ and $\mathrm{Ni}$ bioaccumulation in wheat grains in the object with high-calcium BCA introduced into the soil at a dose corresponding to $1.5 \mathrm{Mg} \mathrm{CaO} \cdot \mathrm{ha}^{-1}$ was poor, while that of $\mathrm{Cu}$ was at the average level. The municipal SSC applied at a dose corresponding to 250 $\mathrm{kg} \mathrm{N} \cdot \mathrm{ha}^{-1}$ induced an average degree of $\mathrm{Mn}, \mathrm{Ni}, \mathrm{Cd}$, $\mathrm{Zn}$ and $\mathrm{Cu}$ bioaccumulation, while in the case of $\mathrm{Pb}$ a poor. In the objects with municipal SSC introduced into the soil with addition of high-calcium BCA (objects $\mathrm{D}$ and $\mathrm{F}$ ), the degree of $\mathrm{Cu}, \mathrm{Mn}, \mathrm{Ni}, \mathrm{Pb}$ and $\mathrm{Zn}$ bioaccumulation in wheat grains was poor, while there was no $\mathrm{Cd}$ accumulation. Whereas, in the objects with high-calcium BCA applied at a dose corresponding to $1.5 \mathrm{Mg} \mathrm{CaO} \cdot \mathrm{ha}^{-1}$ in the first year of this study and to $0.75 \mathrm{Mg} \mathrm{CaO} \cdot \mathrm{ha}^{-1}$ in the second year (object $\mathrm{F}$ ), the degree of $\mathrm{Cu}, \mathrm{Mn}, \mathrm{Pb}$ and $\mathrm{Zn}$ bioaccumulation in wheat grains was poor, while there was lack in $\mathrm{Cd}$ and $\mathrm{Ni}$ bioaccumulation. The degree of $\mathrm{Cd}, \mathrm{Cu}, \mathrm{Mn}, \mathrm{Zn}$ and $\mathrm{Pb}$ accumulation in rapeseeds was poor, while that of $\mathrm{Ni}$ was average in the objects with exclusive introduction of high-calcium BCA into the soil at a dose corresponding to $1.5 \mathrm{Mg} \mathrm{CaO} \cdot \mathrm{ha}^{-1}$ (object $\mathrm{B}$ ) and municipal SSC being applied with the addition of high-calcium BCA (object D). An intense degree of accumulation in rapeseeds characterized $\mathrm{Ni}$ in the object with municipal SSC introduced into the soil at a dose corresponding to $250 \mathrm{~kg} \mathrm{~N} \cdot \mathrm{ha}^{-1}$ (object C), whereas other heavy metals reached an average degree (Table 4).

In the object with high-calcium BCA introduced into the soil (object $\mathrm{E}$ ), a poor degree of accumulation in rapeseeds was observed in case of $\mathrm{Zn}, \mathrm{Mn}, \mathrm{Cu}, \mathrm{Ni}$ and $\mathrm{Pb}$ while there was a lack $\mathrm{Cd}$ bioaccumulation. When it comes to the degree of $\mathrm{Ni}$ accumulation in rapeseeds, it was average and amounted. On the basis of the above up, it was found that the higher content of a given heavy metal introduced into the soil with municipal SSC with and without the addition of high-calcium BCA was the smaller bioaccumulation index in the test plants. After three years of study, the degree of heavy metals accumulation in potato tubers, wheat grains, and rapeseeds remained at a poor and an average level. The studies conducted by Baran et al. and Flus-Bujak et al. show that the complexing properties increase in the soil beding fertilized with composts, produced with municipal sewage sludge through which stable metal-organic combinations are being formed that limit the availability of heavy metals to, plants which finds ist confirmation in the experiment being just performed ${ }^{\mathbf{2 6 - 2 7}}$. The reason of an average bioaccumulation of heavy metals in test plants was alkaline reaction of municipal SSC ( $\mathrm{pH} 8.50)$ and high-calcium BCA (pHKCL 11.0), which influenced a weak mobility of these chemical elements and their low sorption. 


\section{ACKNOWLEDGEMENTS}

Part of the research was carried out in the framework of research and development project No. 0397/R/ $\mathrm{P} 0 / 2008 / 04$.

\section{LITERATURA CITED}

1. Berg, W. \& Fenerbon, H. (2006).Processing and use of ashes. Fly ash from coal in Europe-properties and applications. (NE Poland).Międzynarodowe Seminarium Naukowo-Techniczne Bełchtów. Ekotech Bełchatów 19-252.

2. Kępas, W. (2008). Attempt of recovery of fly ash and slag from thermal treatment of waste as aggregate material. (NE Poland). Gospodarka surowcami mineralnymi, 34(3/3), 149-154.

3. Szymonek, A. (2008). Acquiring of waste of calcium oxide from theashes. (NE Poland). Chem. Proces Engineer., 29:895-908.

4. Brzozowski, B., Kabała, J., Krzyżanowski, P. \& Listkiewicz, J. (2006). Processing and use of ashes. Current state and prospects for the economic use of fly ash BOTin Elektrowni Turów SA. (NE Poland) Materiały Międzynarodowego Seminarium Naukowo-Technicznego, Wydaw. Ekotech, Bełchatów, s. 61.

5. Kovàcik, P., Macàk, M., Ducsay, L., Halcćinovà, M. \& Janćich, M. (2011).Effect of ash-fly ash mixture application on soil fertility. J. Elementology,16(2), 215-225. DOI: 10.5601/ jelem.2011.16.2.05.

6. Bose, S., Jain, A., Rai, V. \& Ramanathan, A.L. (2008). Chemical fractionation and translocation of heavy metals in Canna indica L.grownon industrial soil. J. Hazard. Mater.,160, 187-193. DOI: 0.1016/j.hazmat.2008.02.119.

7. Hargreaves, J.C., Adl, M.S. \& Warman, P.R. (2008). Areview of the use of composted municipal solid waste in agriculture. Agric. Ecosys. Environ., 123, 1-14. DOI: 10.1016/j. agee.2007.07.004.

8. He, M., Tian, G., \& Liang, X. (2009). Phytotoxicity and speciation of copper,inc and lead during the aerobics composting of savage sludge. Journal Hazard. Mater., 163, 671-677. DOI: 10.1016./j.hazmat.2008.07.01.

9. Torri, S., Zubillaga, M. \& Cusato, M. (2009). Potential of discaria americana for metal stabilization on soil samended with biosolidsand ash-spiked biosolids. International J. Phytoremediation, 11(2), 187-199: DOI: 10.1080/15226510802378475.

10. Quant, B. (2000).Countering the any negative effects furnace waste landfillson the environment with the use of sewage sludge. (NE Poland). Ekol. Tech., 8(4), 95-99.

11. Maciejewska, A. \& Wrońska, D. (2003). Developmentof mixtures of sludge-ash in the light of the literature, the applicable law and practice. Circulation of elements in nature (NE Poland). Monografia, 2, 634-642.

12. Kucowski, J., Laudyn, D. \& Przekwas, M. (1997). Energetics and the Environment. (NE Poland).WNT, Warszawa, s:484.

13. Kabata-Pendias, A. \& Pendias, H. (2000).Trace Elements in Soils and Plants. (3 rded.) CRC Press, ss. 413.

14. Michałowski, M. \& Gołaś, J. (2001). Heavy metal content in the bodies of willows as an indicator of her use in the disposal of sewage sludge. (NE Poland). Zesz. Probl. Postęp. Nauk Rol. 477, 411-419.

15. Krzywy-Gawrońska, E. (2013). Effect of combustion wastes and sewage sludge compost on the chemical properties of soil. Polish J. Chem. Technol. 15(3), 48-54. DOI: 10.2478/ pjct-2013-0043.

16. Regulation of the Minister of Environment on municipal sewage sludge. Official J. Law No. 137, item 924 of 2010.

17. Buczek, J., Tobiasz-Salach, R. \& Szpunar-Krok, E. (2007). The use fulness of consumer potatoes and vegetables grown near roads area rzeszowskiego. (NE Poland). Acta Agrophysica,10(2), 293-301.
18. Gondek, K. (2006). The content of various forms of heavy metals in sewage sludge and composts (NE Poland). Acta Agrophys., 8(4), 825-838.

19. Szewczuk, C. (2009). Influence of foliar nutrition on the yield of potato tubers (NE Poland). Annales UMCS, Sec. E, LXIV(1), 7-12.

20. Iżewska, A. (2006). Thecontent of heavy metals in $\mathrm{Mi}$ scanthus sacchariflorus as in dicato for utilization sewage sludge and compost prepared from sewage sludge (NE Poland). Zesz. Probl. Postęp. Nauk Rol., 512, 165-171.

21. Iżewska, A.(2007). Impact of fertilization with manure, sewage sludge and compost prepared from sewage sludge on soil properties. (NE Poland). Zesz. Probl. Postęp. Nauk Rol., 518, 85-92.

22. Patorczyk-Pytlik, B. (2006). Use fullness of the BCR procedure for assessing themobility of $\mathrm{Zn}$ in sewage sludge composted by different metodes (NE Poland). Zesz. Probl. Postęp Nauk Rol., 512 (II), 457-464.

23. Sady, W. \& Smoleń, S. (2004). Impact of factors the soil and fertilizers on the accumulation of heavy metals in plants. (NE Poland). X Ogólnopolskie Sympozjum Naukowe, Efektywność stosowania nawozów w uprawach ogrodniczych, Kraków, 269-277.

24. Hury, G., Podolska, G., Pol-Szyszko, M., Stankowski, S., Ułasik, S. \& Gluba, I. (2007). Successive effect of brown coal ely ash on the quality traits and chemical composition of winter triticale grain (NE Poland). Zesz. Probl. Postęp. Nauk Rol., 518, 77-83.

25. Gibczyńska, M., Meller, E. \& Hury, G. (2007). Effect of brown coal ashes on physical Properties light soil. (NE Poland). Zesz. Probl. Postęp. Nauk Rol., 518, 53-61.

26. Baran, S., Żukowska, G. \& Wójcikowska-Kapusta, A. (2006). Changes in the contents of heavy metal sewage sludge composted with hard coal ashes. (NE Poland). Zesz. Probl. Postęp. Nauk Rol., 512, 39-46.

27. Flis-Bujak, M., Baran, S. \& Żukowska, G. (1996). Properties of organic matter of selected waste of a fertilizer. (NE Poland). Zesz. Probl. Postęp. Nauk Rol., 437, 147-153. 